\title{
Increased expression of the mRNA encoding the somatostatin receptor subtype five in human colorectal adenocarcinoma
}

\section{Vuaroqueaux ${ }^{1}$, A Dutour ${ }^{1,2}, \mathrm{~N}_{\text {Bourhim }}{ }^{1}$, L'H Ouafik $^{3}$, G Monges ${ }^{4}$, $\mathrm{N}_{\text {Briard }}{ }^{1}$, N Sauze ${ }^{1}$, C Oliver ${ }^{1,2}$ and M Grino ${ }^{1}$}

${ }^{1}$ Laboratoire des Interactions Fonctionnelles en Neuroendocrinologie, INSERM U501, IFR Jean-Roche, Faculté de Médecine Secteur Nord, Bvd Pierre Dramard, 13916 Marseille Cedex 20, France

${ }^{2}$ Service d'Endocrinologie, Maladies Métaboliques et de la Nutrition, Hôpital Nord, Chemin des Bourrely, 13915 Marseille Cedex 20, France

${ }^{3}$ Laboratoire des Interactions Cellulaires Intratumorales, IFR Jean-Roche, Faculté de Médecine Secteur Nord, Bvd Pierre Dramard, 13916 Marseille Cedex 20, France

${ }^{4}$ Laboratoire d'Anatomo-Pathologie, Institut Paoli Calmettes, 232 Bvd de Ste Marguerite, 13009 Marseille, France

(Requests for offprints should be addressed to A Dutour, Laboratoire des Interactions Fonctionnelles en Neuroendocrinologie, INSERM U501, IFR Jean-Roche, Faculté de Médecine Secteur Nord, Bvd Pierre Dramard, 13916 Marseille Cedex 20, France; Email: dutour.a@jean-roche.univ-mrs.fr)

\begin{abstract}
Numerous studies have suggested that the antiproliferative potency of somatostatin (SS) analogues may be an efficient tool to improve the prognosis of colorectal cancer. In order to facilitate current efforts to design potent antitumour SS analogues, we studied the distribution of human SS receptors (hsst1-5) mRNAs in a large set of tumoural and normal colonic tissues. Localisation of hsst15 mRNAs in normal and tumoural tissues was performed by in situ hybridisation using radioactive antisense or sense riboprobes. Semi-quantitative analysis of hsst5 mRNA was performed using a computerised image analysis system. Hsst binding sites were characterised by studying the relative potency of SS14, SS28 or SS analogues in displacing $\left[{ }^{125} \mathrm{I}\right] \mathrm{Tyr}^{\circ}-\mathrm{D}-\mathrm{Trp}^{8}$-SS14 bound to HT29-D 4 cells. Hsst5 mRNA was by far the most expressed subtype in both normal and transformed epithelial cells as well as in the HT29-D4 cell line.
\end{abstract}

An increased expression of hsst5 mRNA was found in tumours. Hsst1 mRNA was expressed preferentially as clusters in immune cells in lamina propria and in stroma close to the tumour. A low expression of hsst 4 , hsst 3 and hsst 2 was seen in normal and tumoural tissue. In HT29-D4, binding experiments with SS14 demonstrated the existence of one SS binding class $\left(K_{\mathrm{d}}=524 \mathrm{nM}, \mathrm{B}_{\max }=1 \mathrm{fmol} / 10^{6}\right.$ cells $)$. In competition binding studies, SS28 and BIM23268 (an analogue that shows preferential specificity towards hsst5) effectively inhibited binding of $\left[{ }^{125} \mathrm{I}\right] \mathrm{Tyr}^{\circ}-\mathrm{D}-\mathrm{Trp}^{8}{ }^{-} \mathrm{SS} 14\left(\mathrm{IC}_{50}=15\right.$ and $157 \mathrm{nM}$ respectively), while BIM23197 (an analogue that shows preferential affinity for hsst2) was ineffective. Our results show a high expression of hsst 5 mRNA in human tumoural colonic tissue, while hsst 5 protein is the predominant hsst protein subtype in a tumoural colonic cell line.

Fournal of Molecular Endocrinology (2000) 24, 397-408

\section{INTRODUCTION}

Colorectal cancer is one of the most common cancers in the Western world. The prognosis of patients with advanced colorectal cancer remains poor and new treatment modalities are needed. One of these treatments may involve the use of somatostatin (SS) analogues. SS is a pan-inhibitory peptide widely distributed in the central nervous system and in peripheral tissues. In the gastrointestinal tract it inhibits secretin, gastrin, histamine and gastric acid secretion and decreases gastric and intestinal motility, mesenteric blood flow and intestinal absorption (Lewin 1992). In addition, SS 
inhibits cell proliferation by an inhibition of the release of various hormones and growth factors, an inhibition of angiogenesis, a direct inactivation of growth factors or an activation of programmed cell death (Lamberts et al. 1991, Patel \& Srikant 1997). $\mathrm{SS}$ and its analogues such as octreotide or RC160 inhibit in vitro tumoural colon cell proliferation (Palmer Smith \& Solomon 1988, Qin et al. 1991, Dy et al. 1992). In vivo, in murine colon cancer models and in human tumours grafted to nude mice, these substances reduce tumour volume and metastatic development and decrease tumoural markers (Dy et al. 1992, Qin et al. 1992, Dy \& Morris 1993, Ruszniewski et al. 1993, Davies et al. 1995). However, clinical studies with SS analogues in patients with advanced colorectal cancer failed to demonstrate a significant benefit although a decrease of tumoural markers could be seen (Goldberg et al. 1995, Cascinu et al. 1997); a 2 -week treatment with octreotide decreased the Ki67 kinetic index and the carcinoembryonic antigen level in some patients with primary rectal cancer (Iftikhar et al. 1991). Similarly, octreotide treatment reduced the proliferating cell nuclear antigen-maximum proliferative index (Stewart et al. 1995).

Five human SS receptors (hsst) of seven transmembrane $\mathrm{G}$ protein-coupled types have been cloned (Patel \& Srikant 1997). They are all negatively coupled to adenylate cyclase and can also modulate guanidylate cyclase and calcium or potassium channels, activate protein phosphatase, transmodulate tyrosine kinase type receptors, act on the mitogenactivated protein (MAP) kinase signalling pathway, and even induce apoptosis (Florio \& Schettini 1996, Patel \& Srikant 1997, Pollak \& Schally 1998).

Binding assays and autoradiographic studies have shown the presence of hsst in normal and tumoural colon mucosa, nerve plexus, lymphoid tissue and the peritumoural veins (Iftikhar et al. 1992, Radulovic et al. 1992, Reubi et al. 1992, 1994, 1996). Few recent studies have analysed the expression of the different hsst subtypes in colonic tissue, giving controversial results. Buscail et al. (1996) found by RT-PCR a heterogeneous expression of hsst1-5 in colorectal cancer with a characteristic loss of hsst2 expression in the advanced stages; Laws et al. (1997), using RT-PCR and in situ hybridisation, found a retained expression of hsst 2 but a decreased expression of hsst 5 in late-stage tumours.

In order to get more insight into hsst in colorectal cancer, we studied, using semi-quantitative in situ hybridisation, the expression of hsst1-5 mRNAs in normal and tumoural colonic tissues. We also analysed on a human tumoural cell line (HT29-D4) the binding of $\left.{ }^{125} \mathrm{I}\right] \mathrm{Tyr}^{\circ}-\mathrm{D}-\mathrm{Trp}^{8}-\mathrm{SS} 14$ and its displacement by SS28 or by the newly described SS analogues BIM23268 and BIM23197 that show preferential specificity towards hsst5 and hsst2 respectively.

\section{MATERIALS AND METHODS}

\section{Materials}

Samples were obtained during surgery for colorectal cancer. All patients gave their written consent to participate in the study. The study was approved by the local Ethics Committee (Marseille I). One part of each specimen was used for histopathological classification and individual colon carcinomas were staged according to the Dukes' classification system (Dukes \& Bussey 1958). The other part was immediately frozen on dry ice and stored at $-70{ }^{\circ} \mathrm{C}$. The results of histopathological studies are summarised in Table 1.

\section{Peptides}

SS14 and SS28 were from Bachem (Voisins-leBretonneux, France). BIM23197 (N-hydroxyethylpiperazinyl-acethyl-D-Phe-c[Cys-Tyr-D-TrpLys-Abu-Cys]-Thr- $\mathrm{NH}_{2}$ ) and BIM23268 (c[CysPhe - Phe-D - Trp - Lys - Thr - Phe-Cys] - $\mathrm{NH}_{2}$ ) were provided by Biomeasure Inc. (Milford, MA, USA).

\section{Culture of HT29 cell line}

HT29-D4 human colon adenocarcinoma cell line was routinely cultured in Dulbecco's Modified Eagle's medium (Life Technologies, Cergy Pontoise, France) containing $25 \mathrm{mM}$ glucose, $5 \mathrm{mM}$ glutamine, antibiotics (streptomycin, penicillin) and $10 \%$ heat-inactivated foetal calf serum in $150 \mathrm{~cm}^{2}$ tissue culture flasks for binding assays. For in situ hybridisation studies, cells were cultured for 3 days on Labtek chamber slides (Nalge Nunc International, Roskilde, Denmark). The medium was then removed and cells were rinsed twice with PBS and processed immediately for in situ hybridisation assays.

\section{In situ hybridisation}

Consecutive sections $(12 \mu \mathrm{m})$ were cut on a cryostat microtome at $-20{ }^{\circ} \mathrm{C}$. The sections were thawmounted onto twice gelatine-coated slides, dried on a slide warmer and kept at $-70{ }^{\circ} \mathrm{C}$. Adjacent sections were hybridised with probes recognising the five mRNAs encoding the different hsst subtypes. In situ hybridisation was performed as 
TABLE 1. Histopathological studies of the tumours

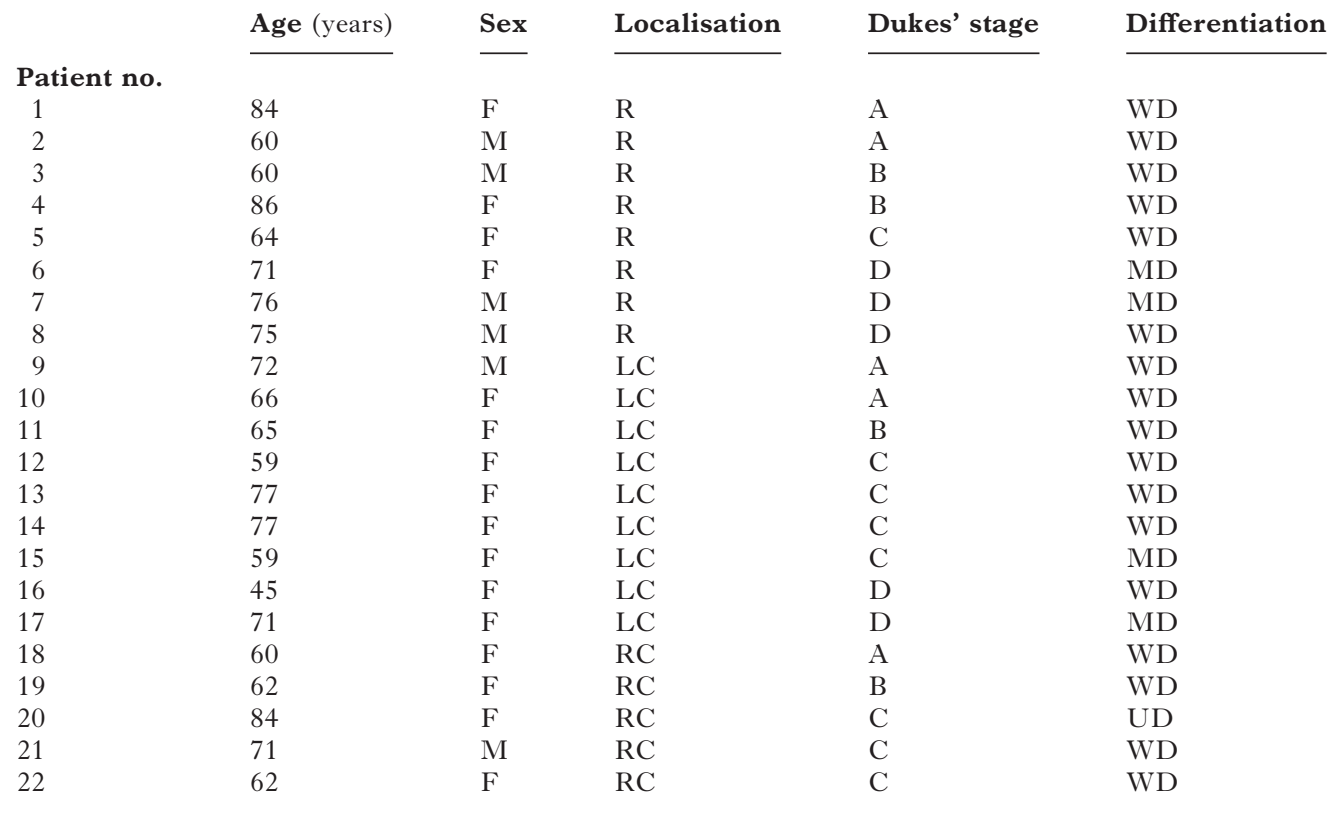

R: rectal; LC: left colon; RC: right colon. WD: well differentiated; MD: moderately differentiated; UD: undifferentiated.

previously described (Grino \& Zamora 1998). Briefly, the sections were warmed at room temperature and fixed with $4 \%$ formaldehyde in PBS, $\mathrm{pH}$ $7 \cdot 2$. After two washes in PBS, they were placed in $0 \cdot 25 \%$ acetic anhydride in $0.1 \mathrm{M}$ triethanolamine$0.9 \% \mathrm{NaCl}, \mathrm{pH} 8$, for $10 \mathrm{~min}$ and delipidated in ethanol and chloroform. They were hybridised with $50 \mu \mathrm{l}$ buffer containing $50 \%$ formamide, $600 \mathrm{mM}$ $\mathrm{NaCl}, 10 \mathrm{mM}$ Tris (pH 7.4), $1 \mathrm{mM}$ EDTA, $10 \%$ (w/v) dextran sulphate, $0.2 \mathrm{mg} / \mathrm{ml}$ tRNA, $100 \mathrm{mM}$ dithiothreitol, and $2 \times 10^{7}$ d.p.m. $/ \mathrm{ml}$ of antisense or sense (control) probe under a glass coverslip. After $20 \mathrm{~h}$ incubation in moist sealed chamber at $56^{\circ} \mathrm{C}$, coverslips were removed in $2 \times \mathrm{SSC}(1 \times \mathrm{SSC}$ is $0.15 \mathrm{M} \mathrm{NaCl}, 0.015 \mathrm{M}$ sodium citrate, $\mathrm{pH} \mathrm{7.2).}$ Slides were subsequently treated for $30 \mathrm{~min}$ at $30{ }^{\circ} \mathrm{C}$ with $10 \mu \mathrm{g} / \mathrm{ml}$ Rnase A in $2 \times \mathrm{SSC}$ and washed at room temperature with decreasing concentrations of $\operatorname{SSC}(2 \times$ to $0 \cdot 1 \times)$ containing $10 \mathrm{mM} \quad \beta$ mercaptoethanol $(\beta-\mathrm{ME})$ and finally incubated for $1 \mathrm{~h}$ at $65{ }^{\circ} \mathrm{C}$ in $0 \cdot 1 \times \mathrm{SSC}, 10 \mathrm{mM} \beta$-ME. Sections were exposed to X-ray films (Biomax-MR; Kodak, Rochester, NY, USA) for $24 \mathrm{~h}$ and subsequently dipped in nuclear emulsion (1:1 in water, K5; Ilford, Saint-Priest, France). In order to get a sufficient but not overexposed signal, antisense and sense slides were exposed for 3 days for hsst5, 9 days for hsst1, hsst 3 or hsst4, and 3 weeks for hsst2, based on the intensity of the signal on the

www.endocrinology.org
X-ray film. After development, sections were counterstained with eosin and haematoxylin.

Labelled riboprobes were prepared using $\left[{ }^{35}\right.$ S $]$ UTP (New England Nuclear, Paris, France, SA: $1300 \mathrm{Ci} / \mathrm{mmol}$ ) and T3 or T7 RNA polymerase (Stratagene, Paris, France) to synthesise sense or antisense transcripts from the hsst1-5 cDNAs cloned into Bluescript. The incorporation of $\left[{ }^{35} \mathrm{~S}\right]$ UTP was comparable for all the antisense or sense probes. The hsst constructs used to generate the ${ }^{35} \mathrm{~S}$-labelled cRNA probes were as follows: 228-1217 for hsst1, 320-1020 for hsst2, 232-1176 for hsst3, 201-1245 for hsst4 and 81-1016 for hsst5. The specificity of these probes has been described previously (Dutour et al. 1998).

\section{Quantification of hybridisation signal}

Hsst5 mRNA hybridisation signal was quantified on emulsion-dipped tissue sections and on monolayers of HT29-D4 cultured cells. Silver grain density was measured under brightfield microscopy (magnification $\times 650$ ) using a computerised image analysis system (Unilog and Ware, Grenoble, France). For each case, three different areas were analysed: the tumoural tissue, morphologically normal tissue adjacent to the tumours and morphologically normal tissue taken at distance $(>3 \mathrm{~cm})$ from the 
tumour. Silver grain density (grains $/ 0 \cdot 1 \mathrm{~mm}^{2}$ ) was measured on ten randomly chosen fields for each area analysed. The mean background level (measured for each tissue on serial sections hybridised with the hsst5 sense probe) was subtracted from each value.

\section{Statistical analysis}

Statistical analysis was performed by the Kolmogorov-Smirnov test, using a computerised program (Stat View 512; Brain Power, Inc., Calabasas, CA, USA).

\section{$\left.{ }^{[25} \mathrm{I}\right] \mathrm{Tyr}^{\circ}$-D-Trp ${ }^{8}$-SS14 binding assay}

${ }^{125}$ I-Labelled Tyr $^{\circ}$-D-Trp ${ }^{8}$-SS14 (specific activity: $2200 \mathrm{Ci} / \mathrm{mmol}$ ) was prepared in our laboratory by lactoperoxidase iodination and purified by reverse phase HPLC (Magnan et al. 1993). The iodinated peptide was diluted $1: 2$ in binding buffer, stored at $4{ }^{\circ} \mathrm{C}$ and used within 3 days. For binding experiments, $10^{6}$ cells/tube were used. Tissue culture flasks were washed twice with $5 \mathrm{ml}$ PBS followed by PBS containing $5 \mathrm{mM}$ EDTA to detach the cells. Binding was performed for $2 \mathrm{~h}$ at $4{ }^{\circ} \mathrm{C}$ in $20 \mathrm{mM}$ Hepes $\mathrm{pH} 7 \cdot 4,5 \mathrm{mM} \mathrm{MgCl}_{2}, 100 \mu \mathrm{g} / \mathrm{ml}$ bacitracin, $230 \mu \mathrm{M}$ phenylmethylsulphonyl fluoride, $100 \mu \mathrm{g} / \mathrm{ml}$ aprotinin, $0.1 \% \mathrm{BSA}$ in a total volume of $0.1 \mathrm{ml}$ containing $0 \cdot 25 \mathrm{nM}\left[{ }^{125} \mathrm{I}\right] \mathrm{Tyr}^{\circ}-\mathrm{D}-\mathrm{Trp}^{8}$-SS14 without (total binding) or with increasing amounts $\left(10^{-11}\right.$ to $\left.10^{-5} \mathrm{M}\right)$ of SS14, SS28, BIM23268 or BIM23197. To test the specificity of the binding, gastrin was also used. The incubation was stopped by diluting the mixture with $5 \mathrm{ml}$ ice-cold $50 \mathrm{mM}$ Tris- $\mathrm{HCl}$ buffer containing 1\% BSA. Separation of free and bound radioligand was obtained by rapid filtration in vacuo through Whatman $\mathrm{GF} / \mathrm{C}$ glassfilter circles $(2.5 \mathrm{~cm}$ diameter $)$, pre-soaked in $50 \mathrm{~mm}$ Tris- $\mathrm{HCl}$ containing $0 \cdot 3 \%$ polyethyleneimine and $0 \cdot 1 \%$ BSA. Filters were washed with $10 \mathrm{ml}$ ice-cold buffer. All assays were performed in triplicate. Radioactivity was counted in a Cobra II (Packard, Warrenville, IL, USA) (99\% efficiency for $\left.{ }^{125} \mathrm{I}\right)$.

\section{Data analysis}

Analysis of binding isotherms was performed by linear regression methods using the LIGAND program (Munson \& Rodbard 1980). Curve fitting and $\mathrm{IC}_{50}$ estimation were performed using the Allfit program (Delean et al. 1978).

\section{RESULTS}

After hybridisation of normal or tumoural tissues with the sense probes, silver grains were sparse and homogeneously distributed, demonstrating the specificity of the probes (Figs 1 and 2B, D, F, H and $\mathrm{J}$ ).

Moderate levels (i.e. detected after 9 days of exposure) of hsst1 mRNA were found in the mucosa, mainly in lamina propria. The labelling was heterogeneous and distributed preferentially as foci in immune cells facing Lieberkühn glands. However, epithelial cells were also clearly labelled (Fig. 1A), Interestingly, no signal was detectable in lymphoid follicles as compared with immune cells in the mucosa. No signal was detected in endothelial, fibroblastic, nervous and muscle cells of the submucosae and in the three muscle layers (muscularis, longitudinal and circular). In tumour, hsst1 mRNA was also expressed by tumoural cells and its expression was heterogeneous within each tumour and between tumours. In many cases, immune cells of stroma close to epithelial cell clusters showed a strong signal (Fig. 2A).

The expression of hsst 2 mRNA was very low (i.e. detected after 21 days of exposure) and sometimes barely detectable (Fig. 1C). Hsst2 mRNA was found in immune cells and in epithelial cells of the mucosa. In tumours, hsst2 subtype was also distributed homogeneously at a very low level in both tumoural epithelial and stromal cells (Fig. 2C).

Hsst 3 mRNA was expressed at moderate levels (i.e. detected after 9 days of exposure) in the mucosa both in epithelial and immune cells (Fig. 1E). The lamina propria was heterogeneously labelled, the density of silver grains being marked in foci located below the cryptic epithelial cells. Hsst 3 mRNA was also expressed in the submucosa. There was a quite marked expression in the three muscle layers. The tumoural distribution pattern of hsst 3 mRNA was more diffuse without any foci (Fig. 2E). Hsst3 mRNA was homogeneously expressed in tumoural cells and immune cells of the stroma.

In the mucosa, hsst4 mRNA had the same distribution pattern as hsst1, the signal being preferentially distributed in immune cells (Fig. 1G). A weak signal was detected in the three muscle layers. In tumours, hsst4 expression was weak and heterogeneous and localised preferentially in immune cells (Fig. 2G).

In normal tissue, hsst5 mRNA was homogeneously expressed at a high level in epithelial cells, already highly detected after 3 days of exposure (Fig. 1I). Moderate levels of hsst5 mRNA were also detected in the three muscle layers, at the interface of the circular and longitudinal layers of the muscle and in endothelial cells. Interestingly, an increased labelling for hsst5 mRNA was found in all the tumours (Fig. 2I, Fig. 3A and B). In all patients analysed, silver grain density of the hsst $5 \mathrm{mRNA}$ 

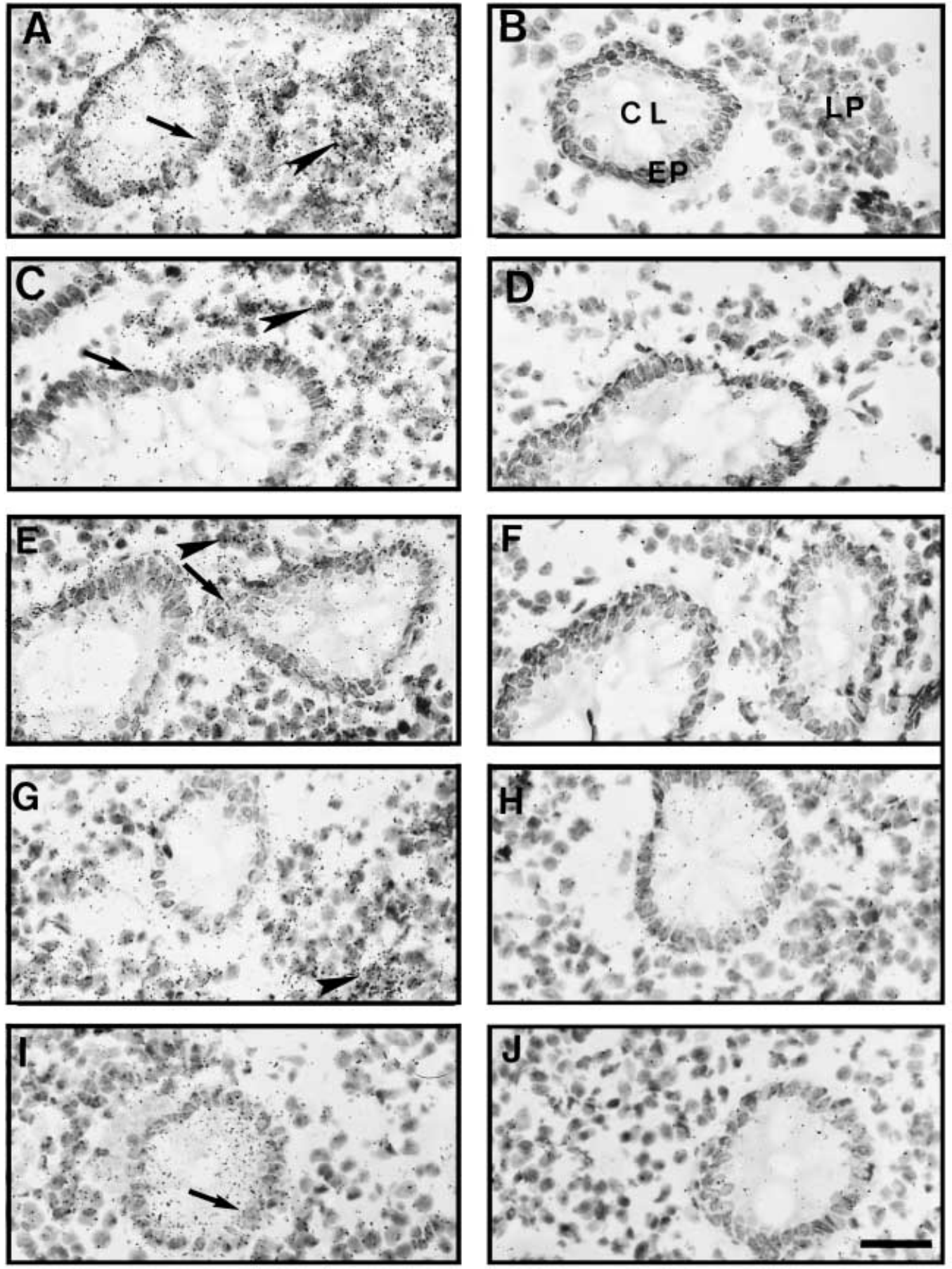

FIGURE 1. Localisation of hsst1-5 mRNA in normal colonic mucosa (patient no. 2) by in situ hybridisation. (A, C, E, G, I) Tissue sections were hybridised with hsst1-5 antisense riboprobes; (B, D, F, H, J) tissue sections were hybridised with hsst1-5 sense riboprobes (control). Tissue sections were exposed for 3 days for hsst5, 9 days for hsst1, hsst 3 or hsst 4 and 21 days for hsst2. Hsst1 mRNA is expressed in immune cells of the lamina propria as foci facing glandular epithelial cells and at low levels in epithelial cells (A). Hsst2 mRNA is expressed at very low levels in both immune and epithelial cells (C). Hsst $3 \mathrm{mRNA}$ is expressed at moderate levels in epithelial cells and in the lamina propria (E). Hsst4 mRNA expression pattern is identical to that of hsst $(\mathrm{G})$. Hsst5 mRNA is expressed at high levels in normal epithelial cells and at lower levels in the lamina propria (I). Arrows indicate epithelial labelling and arrowheads indicate the labelling of immune cell of the lamina propria. CL, crypt of Lieberkühn; EP, epithelium; LP, lamina propria. Bar $=10 \mu \mathrm{m}$. 

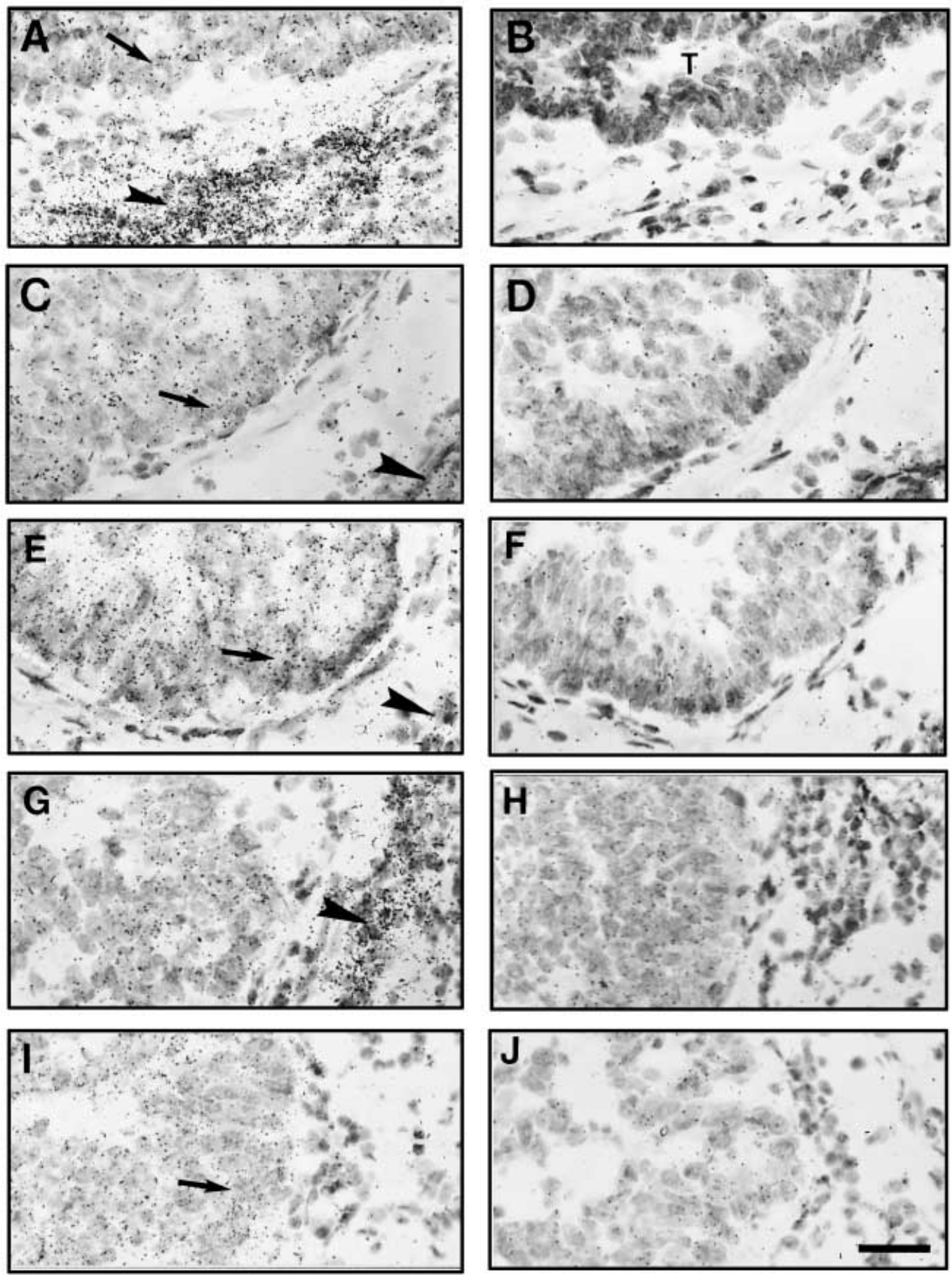

FIGURE 2. Localisation of hsst1-5 mRNA in tumoural colonic tissue (patient no. 2) by in situ hybridisation. (A, C, E, G, I) Tissue sections were hybridised with hsst1-5 antisense riboprobes; (B, D, F, H, J) tissue sections were hybridised with hsst1-5 sense riboprobes (control). Exposure time was as described in the legend of Fig. 1. Hsst1 mRNA is highly expressed as foci by stromal cells (A). Hsst2 mRNA is barely expressed in tumoural and in stromal cells (C). Hsst3 is expressed at a moderate level by transformed epithelial cells and stromal cells (E). Hsst4 is preferentially expressed as foci by stromal cells $(G)$. Hsst 5 mRNA is very intensely expressed in tumoural cells and at a lower level in stromal cells (I). Arrows indicate tumoural labelling and arrowheads indicate the labelling of immune cell of the stroma. T, tumoural cells. Bar $=10 \mu \mathrm{m}$. 

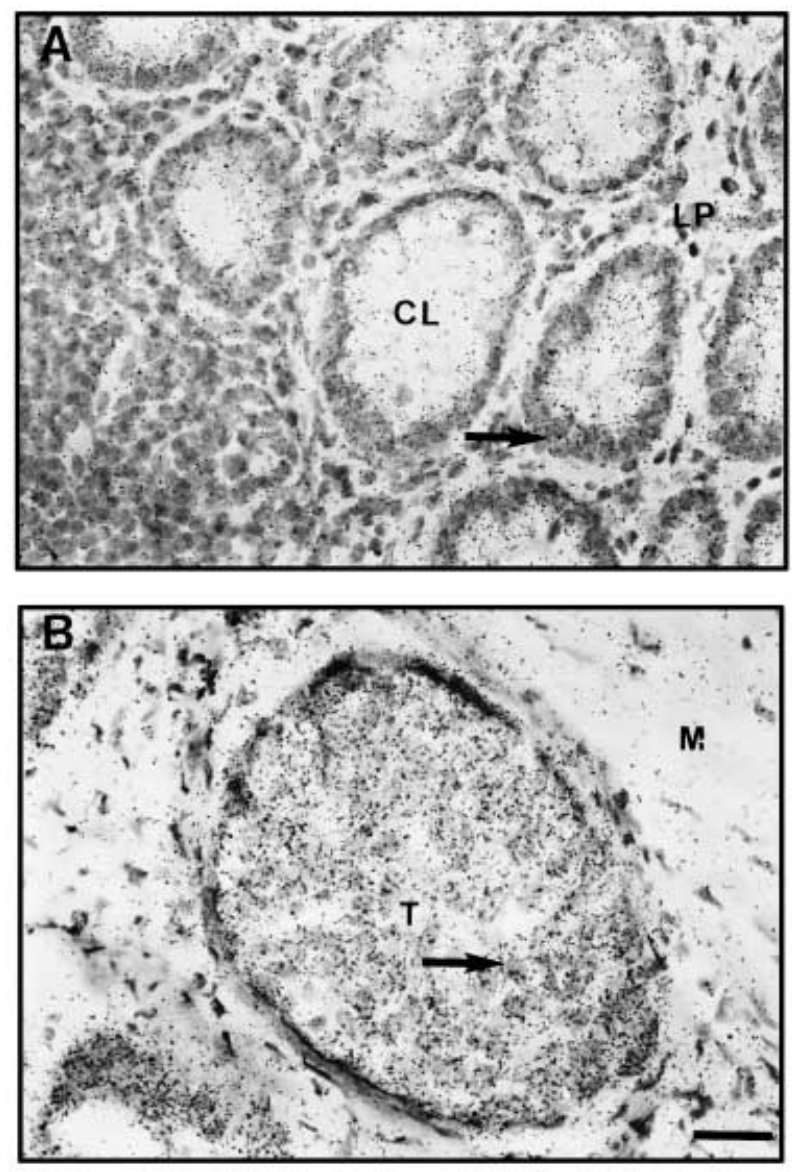

FIGURE 3. Expression of hsst5 mRNA in tumoural cells and normal mucosa sample from patient no. 3. (A) normal tissue; (B) tumoural tissue (Dukes' stage B). Marked labelling of the tumour can be noted (arrows). LP, lamina propria; CL, crypt of Lieberkühn;

$\mathrm{T}$, tumour; M, muscle. Bar $=10 \mu \mathrm{m}$.

hybridisation signal was 2 - to $4 \cdot 5$-fold higher in tumoural tissues than in normal tissue (Fig. 4A). In $88 \%$ of the area analysed in normal tissue less than 30 grains $/ 0 \cdot 1 \mathrm{~mm}^{2}$ were found whereas there was, in $66 \%$ of the area analysed in tumoural tissue, more than 45 grains $/ 0 \cdot 1 \mathrm{~mm}^{2}$. Statistical comparison by the Kolmogorov-Smirnov test indicated a significant $(P<0.001)$ shift towards higher values for hsst5 mRNA in tumours as compared with normal tissue (taken at a distance $>3 \mathrm{~cm}$ from the tumour). Interestingly, a significant difference $(P<0 \cdot 001)$ was also found between morphologically normal tissues taken at distance from the tumour and morphologically normal tissue adjacent to the tumours (Fig. 4B).

The tumoural colonic epithelial cell line HT29-D4 showed the same expression pattern of hsst as in primary tumours with a high level of hsst 5 mRNA, detected after 3 days of exposure (88-132 grains $/ 0 \cdot 1 \mathrm{~mm}^{2}$ ) (Fig. 5A) and a low level of expression of hsst 2 mRNA, which could only be detected after 21 days of exposure (Fig. 5B).

\section{Receptor assays}

The binding of $\left[{ }^{125} \mathrm{I}\right] \mathrm{Tyr}^{\circ}-\mathrm{D}-\mathrm{Trp}^{8}-\mathrm{SS} 14$ to HT29-D4 cell line was found to be temperatureand time-dependent. The total binding was found to be $20 \%$ with $50 \%$ specific binding. No displacement was obtained with gastrin (not shown). Scatchard analysis of the displacement of $\left[{ }^{125} \mathrm{I}\right] \mathrm{Tyr}^{\circ}$-D-Trp ${ }^{8}$-SS14 by native SS14 indicates that HT29-D4 possess a single class of SS binding sites $\left(K_{\mathrm{d}}=524 \mathrm{nM}, \quad \mathrm{B}_{\max }=1 \mathrm{fmol} / 10^{6} \quad\right.$ cells $)$. In competition binding studies, SS28 and BIM23268 (an analogue that shows preferential specificity towards hsst5) effectively inhibited binding of $\left[{ }^{125} \mathrm{I}\right] \mathrm{Tyr}^{\circ}$-D-Trp ${ }^{8}$-SS14 $\left(\mathrm{IC}_{50}: 15\right.$ and $157 \mathrm{nM}$ respectively), while BIM23197 (an analogue that shows preferential specificity towards hsst2) was ineffective ( $\left.\mathrm{IC}_{50}>1 \mu \mathrm{M}\right)$ (Fig. 6).

\section{DISCUSSION}

In view of the many biological actions of SS, particularly in the gut, where SS inhibits endocrine and exocrine secretion, electrolyte and enzyme secretion, electrolyte transport, intestinal nutrient absorption and cell proliferation, an important question that arises is whether these effects are subtype selective. Because of the lack of good sst subtype-selective antagonist, studies on the expression pattern of sst in brain and peripheral tissue have been performed to approach this question. They have revealed an overlapping but characteristic pattern of expression that is subtype, tissue and also species specific (Patel \& Srikant 1997). We present here the first study of the cellular localisation of the five hsst mRNAs in a large set of normal and tumoural human colonic tissue. We found a widespread expression of the five hsst mRNA subtypes in human colonic tissue, particularly expressed in both epithelial and in lamina propria cells. Interestingly, among the different subtypes, hsst5 was by far the most highly expressed and its expression was increased in tumoural cells.

Few studies have approached hsst distribution in normal human colonic tissue (Lewin 1992, Radulovic et al. 1992, Miller et al. 1993, Warhurst et al. 1995, Buscail et al. 1996, Laws et al. 1997). Binding studies have shown the presence of hsst in 


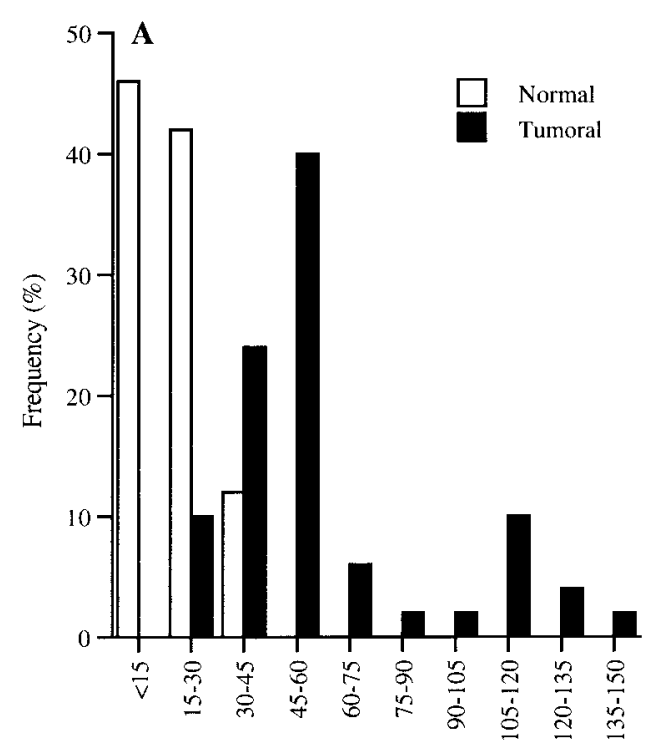

Grains $/ 0.1 \mathrm{~mm}^{2}$

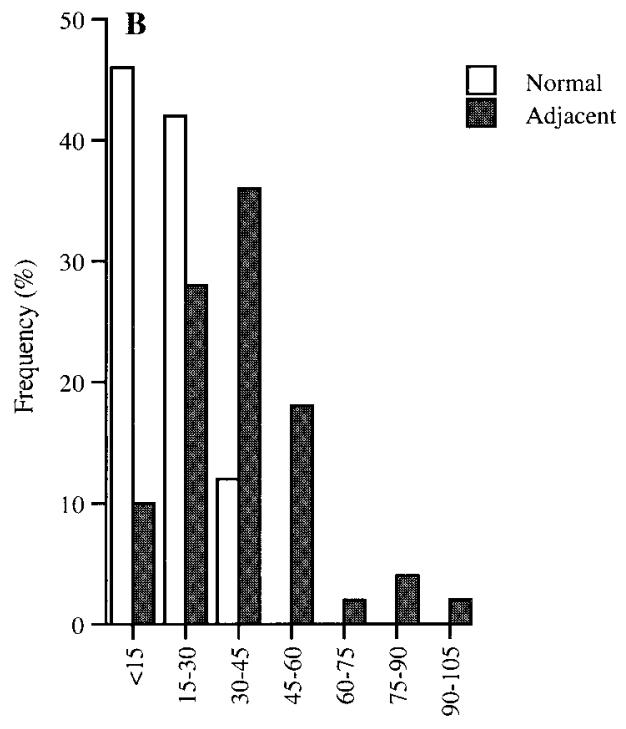

Grains $/ 0.1 \mathrm{~mm}^{2}$

FIGURE 4. Semi-quantitative analysis of $i n$ situ hybridisation signal of hsst5 mRNA.

Quantification was performed using a computerised image analysis system in three different tissue types; tumoural tissue, morphologically normal tissue adjacent to tumoural tissue and morphologically normal tissue taken at a distance from the tumours. Each frequency histogram shows pooled data obtained from five patients (ten fields measured per tissue type per patient). (A) In tumours, silver grain density of hsst $5 \mathrm{mRNA}$ hybridisation signal shifts towards higher values as compared with normal tissues. (B) A shift towards higher values is also found in the morphologically normal tissue adjacent to tumour as compared with normal tissue. Statistical comparison by the Kolmogorov-Smirnov test indicates a significant $(P<0 \cdot 001)$ difference between normal and tumoural or morphologically normal tissue adjacent to tumoural tissue.

normal human mucosa (Radulovic et al. 1992, Miller et al. 1993). Buscail et al. (1996) have shown by RT-PCR the expression of hsst2, hsst 4 and hsst5 in normal human mucosa. As shown by Laws et al. (1997), we demonstrated in a study performed by RT-PCR that all five hsst were detected in normal tissues, hsst5, hsst1 and hsst 2 mRNA being the most frequently detectable (Vuaroqueaux et al. 1999). These non-quantitative results are in accord with our in situ hybridisation results showing a high expression of hsst5 mRNA in epithelial cells, and of hsst $1 \mathrm{mRNA}$ in stroma while hsst 2 was found to be widely expressed in mucosa but at a low level. Using in situ hybridisation, Laws et al. (1997) found that hsst 2 mRNA was widely distributed in normal mucosa and stroma in $90 \%$ of samples while hsst 5 was present only in half of normal mucosal samples. The difference between our results and those of Laws is most probably related to the difference of sensitivity of the probes used. Several studies have been performed in rats. Using RT-PCR, Warhust et al. (1996) have shown that crypt epithelium expressed sst 1 and sst 2 mRNA and, at lower levels, sst 5 mRNA. However, in rat colon adenocarcinoma (DHD/K12) sst2, sst3 and sst5 were identified (Gouyon et al. 1995). A very detailed in situ hybridisation study in the rat gastrointestinal tract has been performed by Krempels et al. (1997) showing a widespread expression of rat sst mRNAs and suggesting a large SS regulatory system in the gastrointestinal tract. Similar to what we found, they showed that all tissues contained mRNA for several sst subtypes. A clear expression of sst3 mRNA was demonstrated, rather comparable with what we found. There is also a close resemblance between sst 1 and sst 4 expression in rat and in human colonic tissue but sst5 expression was far higher in human tissue in our study than in rats. This difference is not surprising as species-specific distribution of sst has previously been shown, the difference of expression being particularly marked for sst5 (Hoefland \& Lambert 1996, Thoss et al. 1996, Patel 1997).

Interestingly, we found expression of hsst1-4 in immune cells of both lamina propria and stroma, hsst1 being the most expressed. This underlines the 

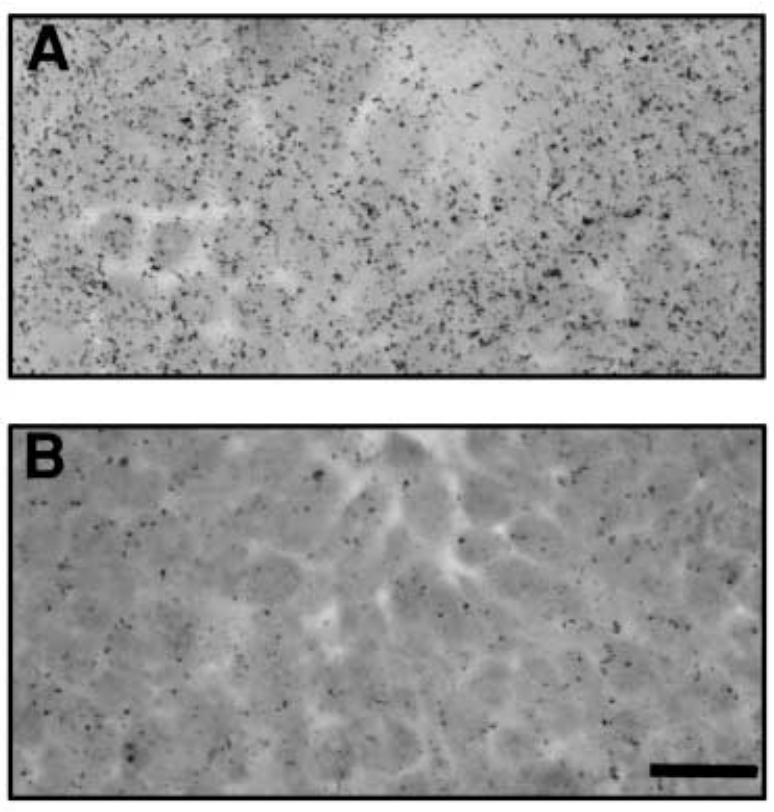

FIGURE 5. Expression of hsst5 and hsst 2 mRNA in the epithelial colonic tumoural cell line HT29-D4. (A and B) Cell culture hybridised with hsst5 and hsst2 antisense riboprobes respectively. (A) High level of hsst 5 mRNA was detected with antisense probe after 3 days of exposure. (B) Very low level of hsst $2 \mathrm{mRNA}$, detectable only after 21 days of exposure. Bar $=10 \mu \mathrm{m}$.

relevance of the immunomodulatory functions of SS (Pawlikowsky et al. 1987, Van Hagen et al. 1994), which is mainly inhibitory, even though SS has also been shown to amplify the immune response in peculiar experimental conditions (Pawlikowski et al. 1989). SS has been shown to act in a paracrine and/or autocrine fashion to inhibit lymphocyte proliferation (Aguila et al. 1996), and to inhibit $\mathrm{T}$ cell activation by interfering with the antigenindependent pathways CD2 and CD28 (Casini et al. 1997). Furthermore, in the gut, it was shown that SS can inhibit immunoglobulin production by mononuclear cells of lamina propria and that these cells display specific high-affinity $\left(K_{\mathrm{d}}=2 \cdot 1 \pm\right.$ $0 \cdot 34 \mathrm{nM})$ hsst, whose subtype was not characterised (Fais et al. 1991). Our data suggest that hsst1 may be a major actor.

Looking for therapeutic bases for SS analogue treatment of colorectal cancer, we studied hsst expression in 22 tumours. We show that the five hsst mRNAs were expressed in all the tumours. The tumoural status did not modify the expression of hsst1-4 although in some cases tumours seemed more labelled because of the higher cell density. By contrast, an enhanced labelling for hsst5 mRNA was found in tumoural cells, silver grain density being 2- to $4 \cdot 5$-fold higher in tumoural tissues than in normal ones. Of interest, hsst5 mRNA was retained in advanced tumours. Using a nonquantitative RT-PCR, Buscail et al. (1996) have previously noted a very frequent expression of hsst5 in tumours (in $71 \%$ of tumours whatever the stage of the tumours) while hsst2 was less frequently detected especially in advanced tumours (three out of six in Dukes' B stage, one out of five in Dukes' C stage, none out of three in Dukes' D stage). Our work underlines the importance of hsst5 in tumours. The group of Primerose (Laws et al. 1997) found also an increased frequency of hsst5 expression in early-stage tumours as compared with normal mucosa ( $75 \mathrm{vs} 45 \%$ ) but this increase of frequency was lacking in late-stage tumours.

Although mRNA steady-state levels do not necessarily correlate with the amount of protein synthesised, the existence of large amounts of hsst 5 mRNA was in favour of the presence of high levels of hsst5. The recent availability of SS analogues with preferential specificity for hsst5 allowed us to show the presence of hsst5 binding sites and a very low level of hsst2 receptor on HT29-D4. Indeed BIM23268, an SS analogue with a higher affinity for hsst5 than for hsst2 and hsst3 (40- and >10 000-fold respectively) (Shimon et al. 1997) was more effective than SS14 itself $\left(\mathrm{IC}_{50}=157 \mathrm{nM}\right.$ vs $628 \mathrm{nM}$ for SS14) in displacing $\left[{ }^{125} \mathrm{I}\right] \mathrm{Tyr}^{\circ}-\mathrm{D}-\mathrm{Trp}^{8}$-SS14 bound to HT29-D4 cells. Furthermore, BIM23197, an SS analogue with a higher affinity for hsst 2 than for hsst5 and hsst3 (50and 140-fold respectively) did not affect the binding of iodinated SS14 to HT29-D4 cells. Our results are in good agreement with the recently published immunohistochemical studies showing the presence of the hsst5 receptor protein in colonic tissue (Estève et al. 1998).

Our results show a high expression of hsst5 mRNA in human tumoural colonic tissue, while hsst5 protein is the predominant hsst protein subtype in a tumoural colonic cell line, and raise the question of the potential benefit of sst5 analogues in colonic cancer therapeutic approaches. Indeed, SS analogues such as octreotide and RC160 have been shown to decrease tumoural markers and the growth of human colonic tumours transplanted in rodents and to reduce metastatic development (Qin et al. 1991, 1992, Dy et al. 1992, Dy \& Morris 1993, Ruszniewski et al. 1993, Davies et al. 1995). These antiproliferative effects of SS are mediated both indirectly through inhibition of secretion of hormones and growth factors involved in tumour growth and directly through sst located on tumour tissue (Lamberts et al. 1991, Patel \& Srikant 1997). 


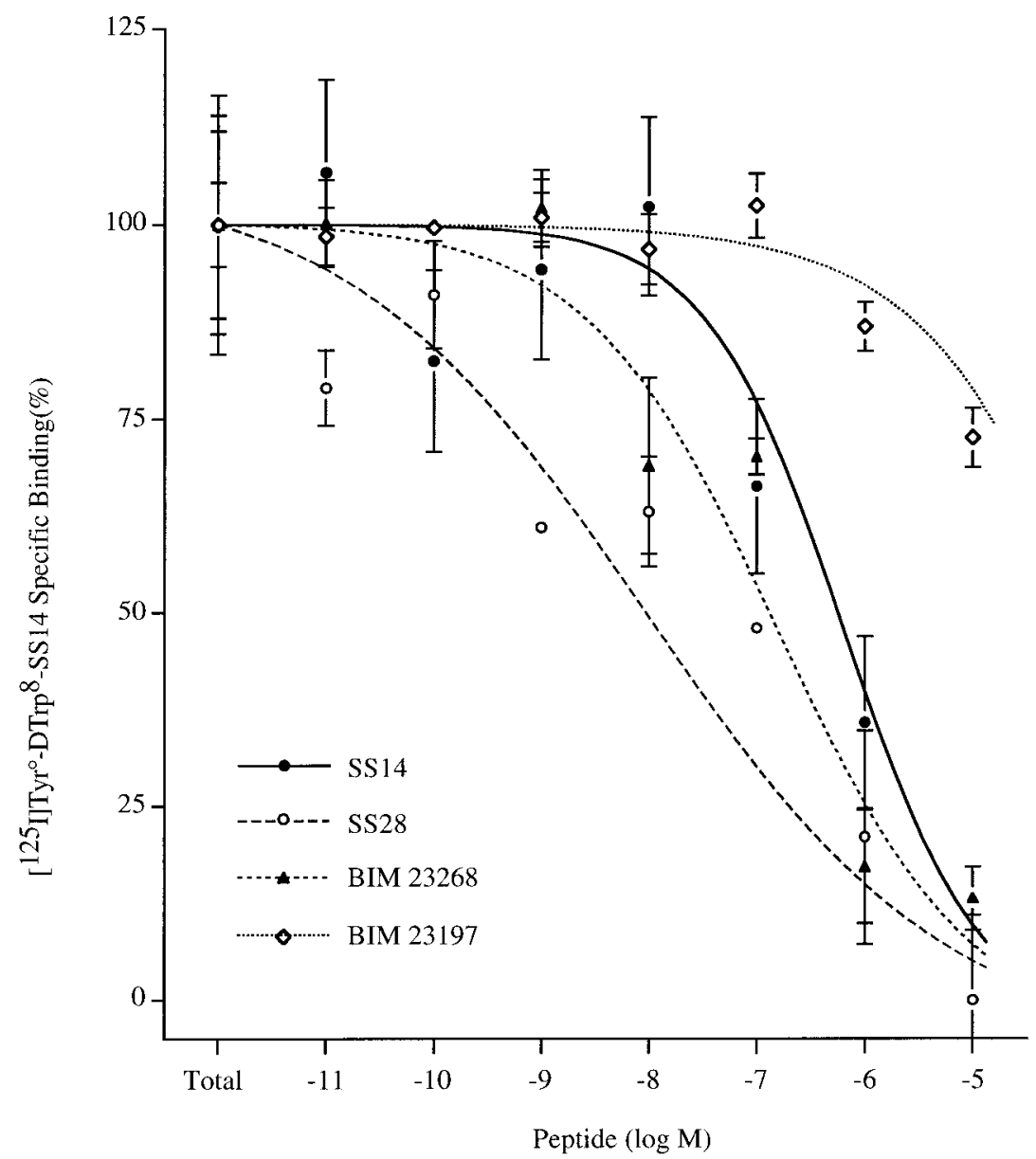

FIGURE 6. Displacement of $\left[{ }^{125} \mathrm{I}\right] \mathrm{Tyr}^{\circ}-\mathrm{D}-\operatorname{Trp}^{8}$-SS14 binding to epithelial colonic tumoural cell line HT29-D4. Cells were incubated for $2 \mathrm{~h}$ at $4{ }^{\circ} \mathrm{C}$ with $0.25 \mathrm{nM}$ iodinated peptide in the absence (total) or in the presence of increasing concentrations $\left(10^{-11}-10^{-5} \mathrm{M}\right)$ of SS14, SS28, BIM23268 or BIM23197. Values are the mean \pm s.E. of three determinations. Results are expressed as the percentage of total specific binding.

Schematically, sst can activate protein tyrosine phosphatases inducing dephosphorylation of growth factor receptor kinase and then inhibit MAP kinase activity (Pan et al. 1992, Buscail et al. 1994, Patel \& Srikant 1997, Pollak \& Schally 1998). Several sst subtypes have been implicated in SS antiproliferative effects (Buscail et al. 1994, Sharma et al. 1996, 1999, Cordelier et al. 1997, Patel \& Srikant 1997, Florio et al. 1999). Even though SS-induced apoptosis has been shown to occur via the hsst3 subtype in cycling cells (Sharma et al. 1996), a large body of experimental evidence suggests involvement of hsst5 in SS-induced antiproliferative effects (Cordelier et al. 1997, Sharma et al. 1999). A cytostatic effect of SS via hsst5 that occurred through induction of the retinoblastoma protein and
G(1) cycle arrest was recently described (Sharma et al. 1999). Moreover, hsst5, the subtype overexpressed in colonic tumours, can inhibit the proliferation induced by cholecystokinin (CCK) (Cordelier et al. 1997). Indeed, when stably expressed in $\mathrm{CHO}$ cells, hsst5 mediates the antiproliferative effect of SS analogues, via the successive inhibition of soluble guanylate cyclase, protein kinase $\mathrm{G}$ and p42 MAP kinase activities (Cordelier et al. 1997). It is interesting to note that we have previously shown in the tumours analysed in this study the presence of CCK-B long and short isoform and CCK-C receptors (Biagini et al. 1997).

In conclusion, our results suggest that studying the effect of hsst5 analogues in colorectal cancers may be an interesting approach. 


\section{ACKNOWLEDGEMENTS}

The authors wish to thank Prof. A Chayvialle (INSERM U45, Lyon), and Dr O PaulmyerLacroix (INSERM U501) for valuable advice and Prof. J-R Delpero (Service de Chirurgie Générale et Oncologique, Institut Paoli Calmettes, Marseille) for his contribution in colorectal samples collection and $\mathrm{Mr} \mathrm{C}$ Allasia for his help in the computerised analysis of the in situ hybridisation samples. This work was supported by grants from the Programme Hospitalier de Recherche Clinique UF 2787. V V is supported by a fellowship from Programme Hospitalier de Recherche Clinique by Assistance Publique des Hôpitaux de Marseille.

\section{REFERENCES}

Aguila MC, Rodriguez AM, Aguila-Mansilla HN \& Lee WT 1996 Somatostatin antisense oligonucleotide-mediated stimulation of lymphocyte proliferation in culture. Endocrinology 137 1585-1590.

Biagini P, Monges G, Vuaroqueaux V, Parriaux D, Cantaloube F \& De Micco P 1997 The human gastrin/cholecystokinin receptors: type $\mathrm{B}$ and type $\mathrm{C}$ expression in colonic tumors and cell lines. Life Sciences 61 1009-1018.

Buscail L, Delesque N, Estè ve J-P, Saint-Laurent N, Prats H, Clerc P, Robberecht P, Bell GI, Liebow C, Schally AV, Vaysse N \& Susini C 1994 Stimulation of tyrosine phosphatase and inhibition of cell proliferation by somatostatin analogues: mediation by human somatostatin receptor subtypes SSTR1 and SSTR2. Proceedings of the National Academy of Sciences of the USA $912315-2319$.

Buscail L, Saint-Laurent N, Chastre E, Vaillant JC, Gespach C, Capella G, Kalthoff H, Lluis F, Vaysse N \& Susini C 1996 Loss of sst2 receptor gene expression in human pancreatic and colorectal cancer. Cancer Research $\mathbf{5 6}$ 1823-1827.

Cascinu S, Del Ferro E, Grianti C, Ligi M, Ghiselli R, Foglieti G, Saba V, Lungarotti F \& Catalano G 1997 Inhibition of tumor cell kinetics and serum insulin growth factor I by octreotide in colorectal patients. Gastroenterology $113767-772$.

Casini C, Lattuada D, Perego C, Fransco P \& Marelli O 1997 Inhibitory effect of somatostatin on human $\mathrm{T}$ lymphocytes proliferation. International Fournal of Immunopharmacology 19 721-727.

Cordelier P, Estè ve J-P, Bousquet C, Delesque N, O'Carroll AM, Schally AV, Vaysse N, Susini C \& Buscail L 1997 Characterization of the antiproliferative signal mediated by the somatostatin receptor subtype sst5. Proceedings of the National Academy of Sciences of the USA 94 9343-9348.

Davies N, Kynaston H, Yates J, Nott DM, Nash J, Taylor BA \& Jenkins SA 1995 Octreotide inhibits the growth and the development of three types of experimental liver metastases. British Fournal of Surgery 82 840-843.

Delean A, Munson PJ \& Rodbard D 1978 Simultaneous analysis of families of sigmoidal curves: application to bioassay, radioligand assay, and physiological dose-response curves. American Fournal of Physiology 235 E97-E102.

Dukes CE \& Bussey HJR 1958 The spread of rectal cancer and its effect on prognosis. British Fournal of Cancer 12 309-320.
Dutour A, Kumar U, Panetta R, Ouafik L'H, Fina F, Ramakrishnan S \& Patel Y 1998 Expression of somatostatin receptor subtypes in human brain tumors. International Fournal of Cancer 76 620-627.

Dy DY \& Morris DL 1993 Somatostatin inhibits both in vivo and in vitro carcinoembryonic antigen secretion by human colon cancer. European Fournal of Surgical Oncology 19 168-172.

Dy DY, Whitehead RH \& Morris DL 1992 SMS 201.995 inhibits in vitro and in vivo growth of human colon cancer. Cancer Research 52 917-923.

Estève JP, Rochaix P, Voigt JJ, Schally AV, Vaysse N, Susini C \& Buscail L 1998 Role of nitric oxide in the antiproliferative signal mediated by the somatostatin receptor sst5. Gastroenterology 114 G4651.

Fais S, Annibale B, Boirivant M, Santoro A, Pallone F \& Delle Fave G 1991 Effects of somatostatin on human intestinal lamina propria lymphocytes. Modulation of lymphocytes activation. Fournal of Neuroimmunology 31 211-219.

Florio T \& Schettini 1996 Multiple intracellular effectors modulate physiological function of the cloned somatostatin receptors. Fournal of Molecular Endocrinology 17 89-100.

Florio T, Yao H, Carey KD, Dillon TJ \& Stork PJS 1999 Somatostatin activation of mitogen-activated protein kinase via somatostatin receptor 1. Molecular Endocrinology 13 24-37.

Goldberg RM, Moertel CG, Wiehand HS, Krook JE, Schutt AJ, Veeder MH, Milliard JA \& Dalton R 1995 A phase III evaluation of a somatostatin analogue (octreotide) in the treatment of patients with asymptomatic advanced colon carcinoma. Cancer 76 962-966.

Gouyon BA, Reyl-Desmars F, Le Romancer M, Pigeon C, Lewin MJM \& Lehy T 1995 In vivo effect of somatostatin analogue, lantreotide, and/or GRP antagonist, BIM 26226, on the growth of colon cancer peritoneal carcinomatosis in the rat. International fournal of Oncology 7 1167-1173.

Grino M \& Zamora AJ 1998 An in situ hybridization histochemistry technique allowing simultaneous visualization by the use of confocal microscopy of three cellular mRNA species in individual neurons. Fournal of Histochemistry and Cytochemistry 46 753-759.

Hoefland LJ \& Lambert SWJ 1996 Somatostatin receptors and disease: role of receptor subtypes. Baillière's Clinical Endocrinology and Metabolism 10 163-176.

Iftikhar SY, Watson SA \& Morris DL 1991 The effect of long acting somatostatin analogue SMS 201-995 therapy on tumour kinetic measurements and serum tumour marker concentrations in primary rectal cancer. British fournal of Cancer 63 971-974.

Iftikhar SY, Thomas WM, Rooney PS \& Morris DL 1992 Somatostatin receptors in human colorectal cancer. European Fournal of Surgical Oncology 18 27-30.

Krempels K, Hunyady B, O’Carroll AM \& Mezey C 1997 Distribution of somatostatin receptors messenger RNAs in the gastrointestinal tract. Gastroenterology 112 1948-1960.

Lamberts SWJ, Krenning EP \& Reubi JC 1991 The role of somatostatin receptors and its analogs in the diagnosis and treatment of tumors. Endocrine Reviews 12 450-482.

Laws S, Gough AC, Evans AA, Bains MA \& Primerose JN 1997 Somatostatin receptors subtype mRNA expression in human colorectal cancer and normal colonic mucosa. British Fournal of Cancer 75 360-366.

Lewin MJM 1992 The somatostatin receptor in the GI tract. Annual Review of Physiology 54 455-468.

Magnan E, Cataldi M, Guillaume V, Mazzochi L Dutour A, Compte Delvox B, Giraud P \& Oliver C 1993 Neostigmine stimulates growth hormone-releasing hormone release into 
hypophysial portal blood of conscious sheep. Endocrinology 132 1247-1251.

Miller GV, Preston SR, Woodhouse LF, Farmery SM \& Primerose JN 1993 Somatostatin binding in human gastrointestinal tissues: effect of cations and somatostatin analogues. Gut 34 1351-1356.

Munson PJ \& Rodbard D 1980 LIGAND: a versatile computerized approach for characterization of ligand-binding system. Analytical Biochemistry 107 220-239.

Palmer Smith J \& Solomon TE 1988 Effects of gastrin, proglumide, and somatostatin on growth of human colon cancer. Gastroenterology 95 1541-1548.

Pan MG, Florio T \& Stork PJS 1992 G protein activation of a hormone-stimulated phosphatase in human tumor cells. Science 256 1215-1217.

Patel YC 1997 Molecular pharmacology of somatostatin receptor subtypes. Fournal of Endocrinological Investigation 20 348-367.

Patel YC \& Srikant CB 1997 Somatostatin receptors. Trends in Endocrinology and Metabolism 8 398-405.

Pawlikowski M, Zelazowski P \& Stepien H 1989 Enhancement of human lymphocytes natural killer activity by somatostatin. Neuropeptides 13 75-77.

Pawlikowski M, Stepien H, Kunert-Radek J, Zelazowski P \& Shally AV 1987 Immunomodulatory action of somatostatin. Annals of the New York Academy of Sciences 496 233-239.

Pollak MN \& Schally AV 1998 Mechanism of antineoplastic action of somatostatin analogs. Proceedings of the Society for Experimental Biology and Medicine 217 143-152.

Qin Y, Shally AV \& Willems G 1991 Somatostatin analogue RC-160 inhibits the growth of transplanted colon cancer in rats. International Fournal of Cancer 47 765-770.

Qin Y, Shally AV \& Willems G 1992 Treatment of liver metastases of human colon cancers in nude mice with somatostatin analogue RC-160. International Fournal of Cancer 52 791-796.

Radulovic SS, Milovanovic SR, Cai RZ \& Shally AV 1992 The binding of bombesin and somatostatin and their analogs to human colon cancers. Proceedings of the Society for Experimental Biology and Medicine 200 394-401.

Reubi JC, Horisberger U, Waser B, Gebbers JO \& Laissue J 1992 Preferential location of somatostatin receptors in the germinal centers of human gut lymphoid tissue. Gastroenterology 103 1207-1214.

Reubi JC, Horisberger U \& Laissue J 1994 High density of somatostatin receptors in veins surrounding human cancer tissue: role in tumor-host interaction. International Fournal of Cancer 56 681-688.
Reubi JC, Mazzucchelli L, Hennig I \& Laissue JA 1996 Local up-regulation of neuropeptide receptors in host blood vessels around human colorectal cancers. Gastroenterology 110 1719-1726.

Ruszniewski P, Lehy T, Reyl-Desmars F, Le Roux S \& Lewin MJM 1993 Octreotide (SMS 201-995) inhibits the growth of colon peritoneal carcinomatosis in BDIX rats. Regulatory Peptides 43 141-147.

Sharma K, Patel YC \& Srikant CB 1996 Subtype-selective induction of wild-type p53 and apoptosis, but not cell cycle arrest, by human somatostatin receptor 3. Molecular Endocrinology 10 1688-1695.

Sharma K, Patel YC \& Srikant CB 1999 C-terminal region of human somatostatin receptor 5 is required for induction of $\mathrm{Rb}$ and $\mathrm{G}(1)$ cell cycle arrest. Molecular Endocrinology 13 82-90.

Shimon I, Taylor JE, Dong JZ, Bitonte RA, Kim S, Morgan B, Coy DH, Culler MD \& Melmed S 1997 Somatostatin receptor subtype specificity in human fetal pituitary cultures: differential role of SSTR2 and SSTR5 for growth hormone, thyroid-stimulating hormone, and prolactin regulation. Fournal of Clinical Investigation 99 789-798.

Stewart GJ, Connor JL, Lawson JA, Preketes A, Kings J \& Morris DL 1995 Octreotide reduces the kinetic index, proliferating cell nuclear antigen-maximum proliferative index, in patient with colorectal cancer. Cancer 76 572-578.

Thoss VS, Perez J, Probat A \& Hoyer D 1996 Expression of five somatostatin receptor $\mathrm{mRNA}$ in the human brain and pituitary. Archives of Pharmacology 354 411-419.

Van Hagen PM, Krenning EP, Kwekkeboom DJ, Reubi JC, Anker-Lugtenburg PJ, Lowenberg B \& Lamberts SWJ 1994 Somatostatin and the immune and haematopoietic system; a review. European Fournal of Clinical Investigation $\mathbf{2 4}$ 91-99.

Vuaroqueaux V, Dutour A, Briard N, Monges G, Grino M, Oliver C \& Ouafik L'H 1999 No loss of sst receptors gene expression in advanced stages of colorectal cancer. European Fournal of Endocrinology 140 362-366.

Warhurst G, Higgs NB, Grigor MR, Ross I \& Barbezat GO 1995 Expression of multiple somatostatin receptor genes in human colonic epithelial cells. Biochemical Society Transactions $2318 \mathrm{~S}$.

Warhurst G, Higgs NB, Fakoury H, Warhurst AC, Garde J \& Coy DH 1996 Somatostatin receptor subtype 2 mediates somatostatin inhibition of ion secretion in rat distal colon. Gastroenterology 111 325-333.

RECEIVED 14 January 2000 